\title{
Phytochemical Screening and Establishment of the Antidiabetic Potential of Aqueous Leaf Extract of the Endangered Plant Decalepis nervosa in Rats with Alloxan-induced Diabetes
}

\author{
Alloksan ile İndüklenen Sıçan Diyabet Modelinde Soyu Tükenmekte \\ Olan Decalepis nervosa Bitkisinin Sulu Yaprak Ekstraktının Antidiyabetik \\ Potansiyelinin Araştırılması ve Fitokimyasal Taraması
}

\author{
(D) Kuntal DAS*, (D) Saifulla KHAN M, (D) James SOUNDER, (D) Usha MOHAN, (D) Venkatesh PRASAD S \\ Krupanidhi College of Pharmacy Department of Pharmacognosy and Phytochemistry, Bangalore, India
}

\begin{abstract}
Objectives: To evaluate the presence of phytochemicals in and the antidiabetic activity of aqueous extract of Decalepis nervosa (AEDN) leaf. Materials and Methods: Either sex rats were grouped into 5 classes. Alloxan monohydrate and glibenclamide were used as diabetes induction drug and standard drug, respectively. Aqueous extract of the endangered medicinal plant DN was used in two different doses. Diabetes was induced with alloxan monohydrate at $150 \mathrm{mg} / \mathrm{kg}$ b.w. The AEDN was standardized with pharmacognostic and phytochemical screening and a chemical test confirmed the presence of phytoconstituents like glycoside, alkaloid, phenols, and flavonoids. Acute toxicity was evaluated for dose selection in an antidiabetic study.

Results: Glibenclamide (5 mg/kg b.w.) and AEDN (200 and $400 \mathrm{mg}$ ) were given to all rats with induced diabetes. The reduced blood glucose level may be correlated with the presence of plant secondary metabolites (phenolic compounds), which was identified by thin layer chromatography and confirmed by high performance liquid chromatography studies. The decreased levels of serum total cholesterol, triglyceride, and liver enzyme activity showed the dose dependency of AEDN extract. An oral glucose tolerance test was performed after administration of 200 and 400 mg of AEDN and $5 \mathrm{mg}$ of glibenclamide to different groups, which showed significantly lower oral glucose load during blood sample collection. Animal body weight and dose of AEDN extract had a significant effect on the glucose level in blood ( $p<0.01$ ).

Conclusion: The first report on the phytochemicals and therapeutic activity of AEDN leaf showed potential antidiabetic activity by increased insulin secretion via enhanced peripheral glucose utilization mechanism.
\end{abstract}

Key words: Alloxan, biochemical estimation, correlation, Decalepis nervosa, phytochemicals

Öz

Amaç: Decalepis nervoza (AEDN) yaprağının sulu ekstraktında fitokimyasalların varlığını göstermek ve antidiyabetik aktivitesini değerlendirmektir. Gereç ve Yöntemler: Her iki cinsiyette sıçan içeren 5 grup oluşturuldu. Alloksan monohidrat ve glibenklamid, sırasıyla diyabet indüksiyon ilacı ve standart ilaç olarak kullanıldı. Soyu tükenmekte olan tıbbi bitki Decalepis nervoza'nın sulu ekstresi iki farklı dozda kullanılmıştır. Diyabet 150 mg/kg alloksan monohidrat ile indüklendi. AEDN, farmakolojik teşhis ve fitokimyasal tarama ile standartlaştırıldı ve kimyasal test, glikozit, alkaloid, fenoller ve flavonoidler gibi fito-bileșenlerin varlığını doğruladı. Antidiyabetik çalışmada doz seçimi için akut toksisite değerlendirildi.

Bulgular: Diyabetli tüm sıçanlara glibenklamid ( 5 mg/kg) ve AEDN (200 ve 400 mg) verildi. Düşük kan şekeri seviyesi, ince tabaka kromatografisi ile tespit edilen ve yüksek performanslı sıvı kromatografisi çalışmaları ile teyit edilen bitki sekonder metabolitlerinin (fenolik bileșikler) varlığı ile ilișkilendirilebilir. Serum toplam kolesterol, trigliserit ve karaciğer enzim aktivitesindeki azalma, AEDN ekstresinin doz bağımlı olarak etki ettiğini gösterdi. 200 ve 400 mg AEDN ve 5 mg glibenklamidin farklı gruplara uygulanmasından sonra bir oral glukoz tolerans testi yapılmıştır; kan örneği

*Correspondence: E-mail: drkkdsd@gmail.com, Phone: 09632542846 ORCID-ID: orcid.org/000-0001-6118-5270

Received: 12.04.2019, Accepted: 20.07.2019

Turk J Pharm Sci, Published by Galenos Publishing House. 
alınması sırasında oral glukoz yükünün önemli ölçüde düşük olduğu saptanmıștır. Hayvanların vücut ağırlığının ve AEDN ekstresi dozunun, kandaki glukoz seviyesi üzerinde önemli bir etkiye sahip $(p<0,01)$ olduğu bulunmuștur.

Sonuç: AEDN yaprağının fitokimyasalları ve terapötik aktivitesini konu alan ilk çalışmadır. Ekstraktın, artmış periferik glukoz kullanım mekanizması yoluyla insülin sekresyonunu arttırarak potansiyel antidiyabetik aktivite gösterdiği bulunmuştur.

Anahtar kelimeler: Alloksan, biyokimyasal tahmin, korelasyon, Decalepis nervoza, fitokimyasallar

\section{INTRODUCTION}

Among the serious metabolic disorders, diabetes mellitus is a most critical disorder throughout the world, with India listed in the top three countries. It is life threatening and responsible for many complications (such as retinopathy, neuropathy, and angiopathy) affecting various organs in the body, especially the eyes, followed by dysfunction and failure of various functional organs. Ample numbers of medicines are available in the world pharmaceutical market, but the related complications are increasing day by day. Hence traditional natural healing is an alternate method for its treatment. Herbal plants are known as a source of natural medicines. A literature survey revealed that a vast number of plants are used for their hypoglycemic activities with very few or no side effects.' Hence searching for phytoconstituents in novel antidiabetic plants without side effects is the main focus.

Of late, Decalepis nervosa (DN) (Wight and Arn.) Venter has become an endangered species of the genus Decalepis and family Apocynaceae. DN is a medicinal plant, distributed throughout the Western Ghats and the Nilgiris, occupying the western corner of Tamil Nadu, which borders Karnataka and Kerala states. The plant is a woody climbing shrub; its stem is purplish and pubescent and the leaves contain milky latex. Simple leaves are oppositely arranged. Its leaves are elliptical and acute. ${ }^{2}$ There are many reports available on other species for their phytochemicals as well as medicinal activities but no such research evidence is available on DN leaves. ${ }^{3}$ It is worthwhile to quantitatively determine the phytoconstituents like flavonoids and total phenolics present in the leaf, which is important for correlation with the present study. Therefore, the present study involved phytochemical screening in relation to the antidiabetic potential of aqueous leaf extract of DN and this is the first report on this plant for any therapeutic application with possible mechanism of action.

\section{MATERIALS AND METHODS}

\section{Plant material and extract preparation}

DN leaves were collected from the forest area of Coimbatore, Tamil Nadu (Western Ghat Region) and authenticated by the botanist Prof. P.E. Rajashekaran, Principal Scientist, Department of Biotechnology, IIHR, Hessaraghatta, Bangalore (Figure 1). A voucher herbarium specimen, number DN-317/ $\mathrm{KCP} / 2018$, was preserved in the Pharmacognosy Department of Krupanidhi College of Pharmacy, Bangalore. The leaves were shade dried and coarsely powdered by grinder and stored in an airtight container at room temperature.

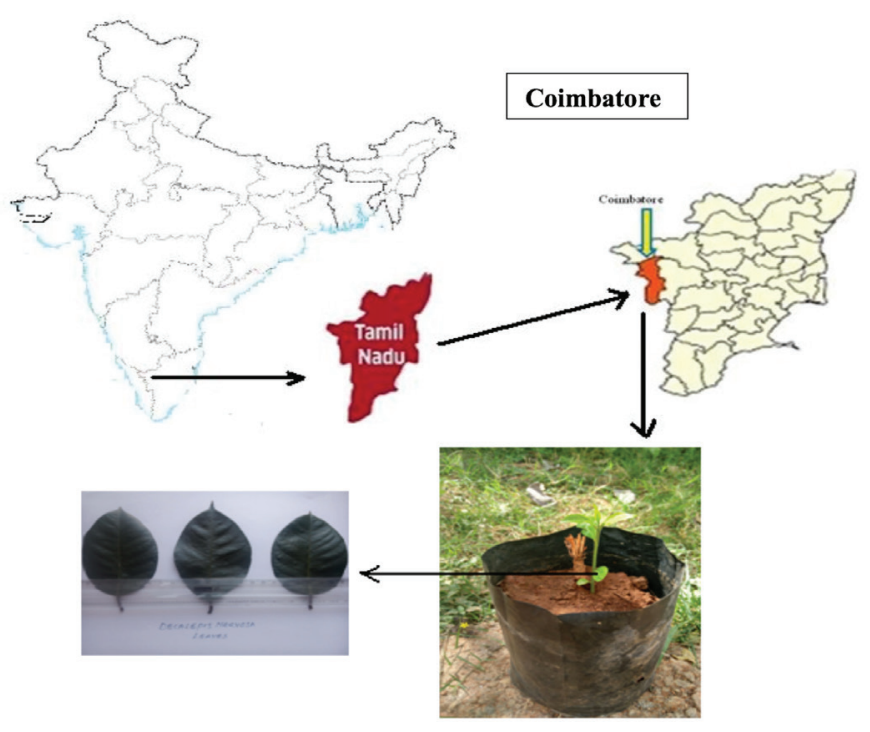

Figure 1. Collection of plant sample (DN leaves) DN: Decalepis nervosa

DN powered leaf $(500 \mathrm{~g}$ ) was used for extraction by distilled water using reflux method for $6 \mathrm{~h}$. Then the extract was filtered and concentrated using a rotary flash evaporator at $45^{\circ} \mathrm{C}$. The percentage yield was reported. The extract was preserved in a refrigerator at $4{ }^{\circ} \mathrm{C}$ in a glass bottle until further use.

\section{Phytochemical analysis}

A preliminary chemical test was performed for the leaf extract by various chemical tests as reported by Trease and Evans. ${ }^{4}$ Furthermore, thin layer chromatography (TLC) of the extract was carried out with a standard phenolic compound (gallic acid) and flavonoids (epicatechin, catechin, and rutin).

\section{Estimation of total flavonoids}

Total flavonoid content was estimated by comparing with standard rutin $(25,50,150,300$ and $600 \mu \mathrm{g} / \mathrm{mL})$ with added aluminum trichloride. Next $125 \mu \mathrm{L}$ of extract solution was added with $75 \mu \mathrm{L}$ of $5 \% \mathrm{NaNO}_{2}$ solution. The mixture was left to stand for $10 \mathrm{~min}$ and thereafter $10 \%$ aluminum trichloride $(150 \mu \mathrm{L})$ was added followed by incubation for $5 \mathrm{~min}$. After that $750 \mu \mathrm{L}$ of $1 \mathrm{M} \mathrm{NaOH}$ was added and the final volume of the solution was adjusted with distilled water up to $2500 \mu \mathrm{L}$. A pink color appeared after $15 \mathrm{~min}$ of incubation and then the absorbance was measured (at $510 \mathrm{~nm}$ ) for the solution. From the standard curve of rutin, the total flavonoid content was measured and expressed as $\mathrm{mg} \mathrm{E}$ catechin/g dry matter. ${ }^{5}$ 


\section{Estimation of total phenolics}

Total phenolics in aqueous extract of DN (AEDN) were determined by spectrophotometry using the Folin-Ciocalteu assay. First, $1 \mathrm{~mL}$ of AEDN was mixed in distilled water ( 9 $\mathrm{mL}$ ) and then $1 \mathrm{~mL}$ of Folin-Ciocalteu reagent was added to the solution. After $10 \mathrm{~min}, 7 \%$ sodium carbonate solution (10 mL) was added and the final volume was made up to $25 \mathrm{~mL}$. Standard solutions of gallic acid were prepared at various concentrations $(20,40,60,80$, and $100 \mu \mathrm{g} / \mathrm{mL})$. The mixed solution was kept for $2 \mathrm{~h}$ at $25 \pm 2{ }^{\circ} \mathrm{C}$ and then absorbance was recorded (at 550 $\mathrm{nm}$ ) for both test and standard solutions. A blank sample was prepared for reading corrections. The phenolics content was estimated and expressed as $\mathrm{mg}$ of gallic acid equivalent of extract. $^{6}$

\section{Acute oral toxicity studies}

As per the Organisation for Economic Co-operation and Development (OECD) guideline (guideline no. 423), the acute oral toxicity studies of AEDN were carried out in July 2018 after approval was received from the CPCSEA meeting held in Krupanidhi College of Pharmacy, Bangalore. ${ }^{7}$ A minimum number of animals ( $n=3$ ) were kept fasting overnight with only drinking water and the next day administration of the AEDN was carried out in the test animals. The AEDN dose was administered and the animals were kept overnight under observation followed by observation for up to 7 days for any changes in general behavior and other physical activities. After $24 \mathrm{~h}$, no animal deaths were observed, which indicates safe action of the aqueous extract.

\section{Experimental animals and their grouping}

Adult albino Wistar rats (150-200 g) of either sex were procured from Adithi Biosys, Tumkur, and maintained in the animal house of Krupanidhi College of Pharmacy. The animals were well acclimatized under controlled temperature $\left(22 \pm 5{ }^{\circ} \mathrm{C}\right)$ and humidity $(55 \pm 5 \%)$. Twelve-hour light and dark cycles were maintained and, as a basal diet, standard pellets obtained from Sri Manjunatha Rice Mill, Ganagular Panchayathi, Hosakote Taluk, were used during the experimental period and all the animals were given normal food and drinking water ad libitum. All experiments were conducted as per the ethical norms approved by the CPCSEA and ethical clearance was granted by institutional ethical committee on 14 February 2018 at Krupanidhi College of Pharmacy, Bangalore (IAEC reg. no: KCP/PCOL/15/2018). Drugs like alloxan monohydrate, used for inducing diabetes, and glibenclamide as standard drug, glucose, Accu-chekÆE Active Glucometer, to check glucose level, and blood glucose strips were used.

The study was conducted on 40 Wistar albino rats randomly allocated to each of the five groups $(8 \times 5=40)$. The groups were treated as follows:

Group I: Normal rats, no treatment, only water and food.

Group II: Diabetic rats treated with alloxan (150 mg/kg b.w.) by i.p. injection.
Group III: Induced diabetic rats with orally given DN aqueous leaf extract $(200 \mathrm{mg} / \mathrm{kg}$ b.w.) once daily for 28 days (Induced diabetic+DN $200 \mathrm{mg} / \mathrm{kg}$ ).

Group IV: Induced diabetic rats with orally given DN aqueous leaf extract ( $400 \mathrm{mg} / \mathrm{kg}$ b.w.) once daily for 28 days (Induced diabetic+DN $400 \mathrm{mg} / \mathrm{kg}$ ).

Group V: Induced diabetic rats with standard glibenclamide at 5 $\mathrm{mg} / \mathrm{kg}$ b.w. once daily for 28 days (oral).

After experimentation, the rats were sacrificed by cervical decapitation and blood was collected with ethylenediaminetetraacetic acid (EDTA) as anticoagulant and plasma was separated by centrifuging the blood at $3000 \mathrm{rpm}$ for $20 \mathrm{~min}$. The serum was separated from the blood without EDTA and centrifuged at $6000 \mathrm{rpm}$ for $10 \mathrm{~min}$.

\section{Induction of diabetes}

The animals were acclimatized for 1-2 weeks and then a freshly prepared solution of alloxan monohydrate (dissolved in $0.9 \%$ normal saline solution) at a dose of $150 \mathrm{mg} / \mathrm{kg}$ body weight was injected i.p. into the experimental rats. Hyperglycemic rats were determined after treating with alloxan by tail vein blood glucose level with the help of a glucometer. A concentration of glucose level $>250 \mathrm{mg} / \mathrm{dL}$ was considered to indicate hyperglycemia in the experiment. ${ }^{8}$

\section{Oral glucose tolerance test (OGTT)}

Fasted rats were separated into four groups, each with eight animals. Group I: treated as control, group II: treated with standard drug, groups III and IV: different extracts. All rats were orally treated with glucose $(2 \mathrm{~g} / \mathrm{kg}$ ) after $30 \mathrm{~min}$ of extract administration. The blood samples were collected from the rat tail vein just before glucose administration ( 0 min) and after glucose administration (every after half an hour, i.e. at 30, 60, and $90 \mathrm{~min}$ ). ${ }^{9}$ A glucometer was used to measure blood glucose levels in the animals.

\section{Body weight measurement}

During the course of the study period, body weight was recorded five times, i.e. before alloxan (initial values), day 0 , and days 7, 14, 21, and 28 of the total treatment period. A digital weighing balance was used and initial body weight and final body weight were recorded. ${ }^{10}$

\section{Estimation of blood glucose level ${ }^{11}$}

Blood samples were collected at weekly intervals up to the end of the study (i.e. 4 weeks). Blood glucose was estimated by one touch electronic glucometer using blood glucose strips. On day 28 , blood was collected from the retro-orbital plexus (carbon dioxide gas used for anesthesia) from overnight fasted rats and blood sugar (fasted) was estimated. Separated serum was analyzed for serum cholesterol and serum triglycerides by enzymatic DHBS colorimetric method, and serum High-density lipoprotein (HDL), serum low-density lipoprotein (LDL), serum creatinine, and serum urea as well as the activities of alkaline phosphatase (ALP), aspartate, and alanine transaminases (AST and $A L T$ ) were determined using Randox Assay kits. 


\section{Statistical analysis}

The results were analyzed by comparing values for the control and the different treated groups and expressed as mean \pm standard error of the mean. One-way analysis of variance followed by Dunnet's t-test for multiple comparisons was applied. Values of $p<0.05$ were considered significant. Further blood glucose was tested based on the dose and body weight of animals using a $2 \times 2$ full factorial design with replicates (Table 1 ). Eight experiments were constructed, varying the dose and body weight using the software JMP version 11. Using this design the magnitude of the effect of each parameter on the resulting response of blood glucose was calculated. Each parameter was tested at 2 levels, i.e. dose (low, $200 \mathrm{mg}$ and high, $400 \mathrm{mg}$ ) and body weight (low, 150 $\pm 5 \mathrm{~g}$ and high $190 \pm 5 \mathrm{~g}$ ).

\section{RESULTS AND DISCUSSION}

\section{Primary phytochemical evaluation}

Extraction of DN plant was carried out and the percentage yield was calculated as $5.28 \%(26.4 \mathrm{~g} \mathrm{w} / \mathrm{w})$. Chemical tests of an aqueous extract of a new plant like DN were carried out and revealed the presence of phytoconstituents like alkaloids, flavonoids, glycoside, and phenols, which play an important role in controlling diabetes. Furthermore, TLC of extract in chloroform, methanol, and water as mobile phase (6:3:1) showed

\begin{tabular}{llll}
\multicolumn{4}{l}{ Table 1. $\mathbf{2}$ 2 full factorial model } \\
Runs & Pattern & Dose in $\mathbf{m g}$ & Body weight in $\mathbf{g}$ \\
\hline 1 & +2 & 400 & High \\
\hline 2 & -1 & 200 & Low \\
\hline 3 & +2 & 400 & High \\
\hline 4 & +1 & 400 & Low \\
\hline 5 & -2 & 200 & High \\
\hline 6 & -2 & 200 & High \\
\hline 7 & -1 & 200 & Low \\
\hline 8 & +1 & 400 & Low \\
\hline
\end{tabular}
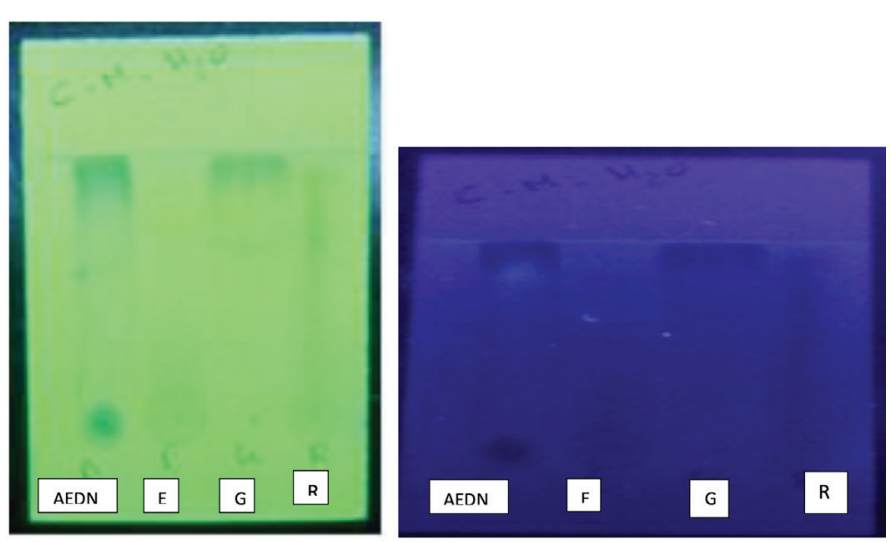

Figure 2. TLC of DN extract with standard drugs for identification of compound

TLC: Thin layer chromatography, DN: Decalepis nervosa, AEDN: Aqueous extract of Decalepis nervosa, E: Ellagic acid, G: Gallic, R: Rutin the presence of phenolics (gallic acid) and flavonoid (rutin) in the extract (Figure 2), which was further confirmed with the high performance liquid chromatography (HPLC) study. HPLC data showed retention time $\left(R_{t}\right)$ of standard rutin and standard gallic acid at $7.58 \mathrm{~min}$ and $3.10 \mathrm{~min}$, respectively, at $203 \mathrm{~nm}$ with the mobile phase methanol:water (60:40) (Figures $3 a$ and $3 b$ ). The same conditions were used for the AEDN extract and showed the presence of these two compounds (rutin and gallic acid) in the extract with $R_{t}$ of 7.58 min and $3.10 \mathrm{~min}$, respectively (Figure

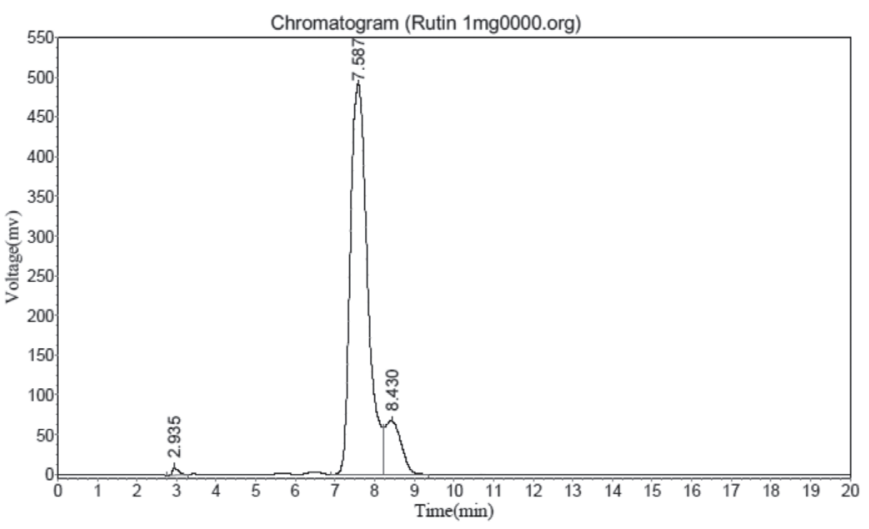

Figure 3a. HPLC of standard rutin (97\% purity) HPLC: High performance liquid chromatography

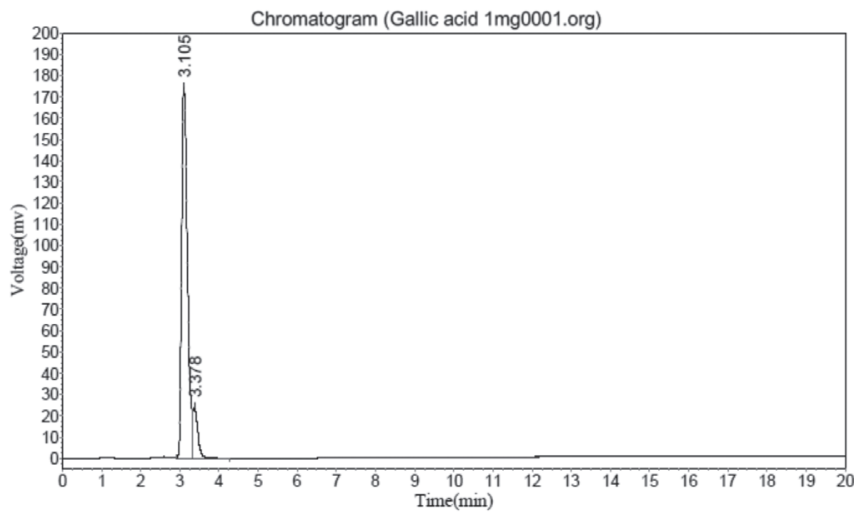

Figure 3b. HPLC of standard gallic acid (98\% purity) HPLC: High performance liquid chromatography

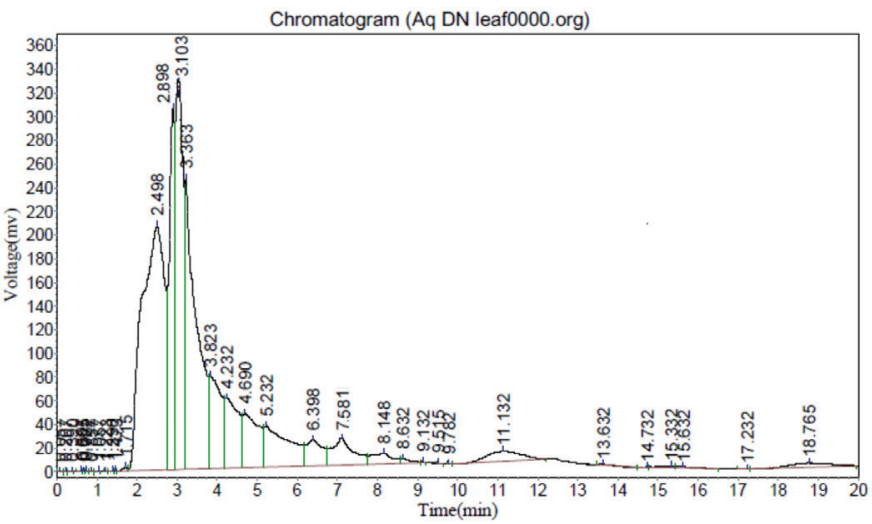

Figure 3c. HPLC of DN aqueous leaf extract HPLC: High performance liquid chromatography 
3c). Furthermore, the amounts were estimated by comparing with standards and it was found that higher amounts of gallic acid were present $(2.32 \mu \mathrm{g})$ in the leaf than rutin $(0.054 \mu \mathrm{g})$. Hence the two compounds gallic acid and rutin were identified in DN extract for the first time in the present investigation.

Phytochemical evaluation with respect to chemical tests is required to identify preliminary phytoconstituents present in herbal extracts. Plant phytoconstituents are essential for therapeutic efficacy. Hence, the chemical test indicates the possible mechanism for the particular disease treatment as well as the discovery of novel drugs from the isolated constituent. Mechanisms of action of phytoconstituents involve regulating glycemic metabolism or decreasing cholesterol levels or increasing secretion of insulin or by improving microcirculation. The present investigation was carried out for qualitative identification of the phytoconstituents present in the aqueous extract of DN, an endangered plant species. Aqueous extract was selected because most of the important phytoconstituents related to antidiabetic activity are soluble in aqueous solvent. Furthermore, aqueous solvent is more cost effective and easily available than other solvents, and in future for preparation of herbal formulations aqueous extract of plant samples is widely acceptable.

\section{Estimation of total flavonoids and total phenolics}

The catechin solution of concentration (25-600 ppm) conformed to Beer's law at $510 \mathrm{~nm}$ with a regression coefficient $\left(R^{2}\right)$ of 0.997 . The plot has a slope of 0.000 and an intercept of 0.031 . The equation of the standard curve is $y=0.000 x+0.031$ (Figure 4; Table 2) and the amount found was $2.52 \mathrm{mg}$.

The total phenolics in AEDN were determined using standard gallic acid. The gallic acid solution of concentration (20-100 ppm) conformed to Beer's law at $550 \mathrm{~nm}$ with a $\mathrm{R}^{2}$ of 0.997 . The plot has a slope $(\mathrm{m})$ of 0.012 and an intercept of 0.025 . The equation of the standard curve is $y=0.012 x+0.025$ (Figure 5; Table 2) and the amount found was $5.81 \mathrm{mg}$.

\section{Table 2. Total flavonoids and total phenolics content in aqueous} extract of DN

\begin{tabular}{llll} 
Extract & Part used & $\begin{array}{l}\text { Total flavonoids } \\
(\mathrm{mg} / \mathrm{g})\end{array}$ & $\begin{array}{l}\text { Total phenolics } \\
(\mathrm{mg} / \mathrm{g})\end{array}$ \\
\hline Aqueous extract of DN & Leaves & $0.52 \pm 0.18$ & $0.58 \pm 0.02$ \\
\hline
\end{tabular}

DN: Decalepis nervosa

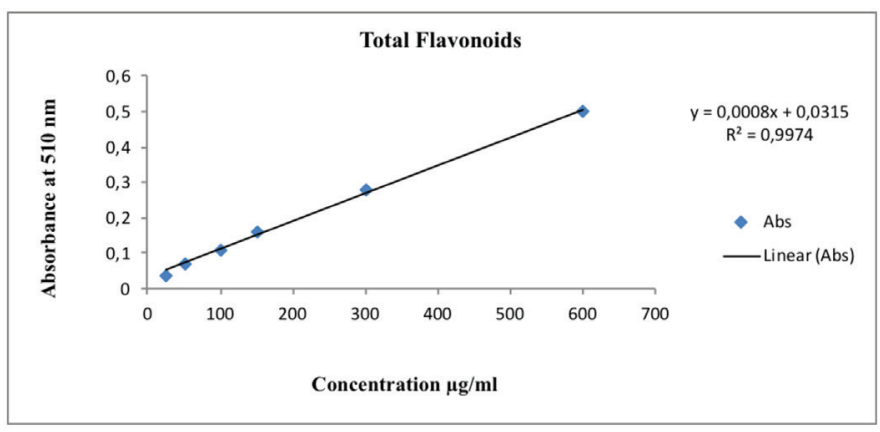

Figure 4. Estimation of total flavonoids with respect to standard catechin
Table 2 indicates the amounts of flavonoids and phenolics are present in quite high amounts. It was evident that higher concentrations of phenolics as well as flavonoids are highly soluble in polar solvents like water. ${ }^{12}$ They mainly act as antioxidants and play a vital role in antidiabetic activity due to the presence of hydroxyl groups, some double bonds, and ketonic functional groups in their structures. ${ }^{13,14}$ Therefore, it was essential to determine the total contents of flavonoids and phenolics in AEDN leaf.

\section{Acute oral toxicity study of Decalepis nervosa leaf extract}

The nontoxic nature of the AEDN is revealed by acute oral toxicity. There were no lethality or toxic reactions found until a dose of $5000 \mathrm{mg} / \mathrm{kg}$ as per the OECD guideline up to the end of the study period. All the animals were alive, healthy, and active during the observation period, which indicates the selected plant extract is safe for the present experiment and two suitable doses were selected, i.e. $200 \mathrm{mg} / \mathrm{kg}$ b.w. and $400 \mathrm{mg} / \mathrm{kg}$ b.w.

An acute toxicity study of AEDN leaf was carried out to determine the lethal dose $\left(L D_{50}\right)$. The study confirmed $L D_{50}$ when two selected doses resulted in mortality higher than $0 \%$ and lower than $100 \%$. Previous reports have described safety dose determination and so the present study was performed for new endangered plant species and the selected doses were safe for further investigation. ${ }^{15,16}$

\section{Oral glucose tolerance test}

The effects of AEDN on the OGTT in normal rats were estimated. After $30 \mathrm{~min}$ of glucose administration a rapid increase in blood glucose occurred in the fasting animals and then decreased subsequently during the time intervals. The standard glibenclamide administered group ( $5 \mathrm{mg} / \mathrm{kg}$ ) had reduced hyperglycemia (glucose induced) significantly at $30 \mathrm{~min}, 60 \mathrm{~min}$, and $90 \mathrm{~min}(103.32 \pm 0.10,102.11 \pm 0.01$, and $84.60 \pm 0.11$, respectively) as compared to the normal control group at the same time intervals. Maximum glucose tolerance in AEDN was observed as $92.22 \pm 0.03$ and the minimum was observed as $87.22 \pm 0.11$ in 90 min as compared with group I (Table 3) ( $p<0.01)$.

The OGTT was carried out to measure the ability to use a type of sugar by the body. The results revealed a dose-dependent reduction in glucose when treated with DN extract orally due to the identified flavonoids and phenolics in AEDN leaf. ${ }^{17}$

Gallic acid

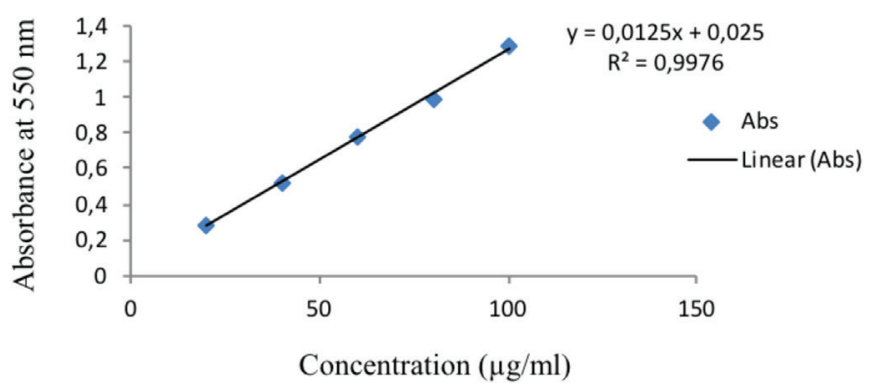

Figure 5. Total phenolic content with respect to standard gallic acid 


\section{Body weight determination}

The body weights of all rats were calculated before alloxan induction, day 0 , and days $7,14,21$, and 28 and the results are given in Table 4. In group II body weight initially increased followed by a significant reduction on days $21(156.19 \mathrm{~g})$ and 28 $(150.11 \mathrm{~g})$ compared to the initial day $(174.10 \mathrm{~g})$. Groups IV and $V$ also showed a significant reduction $(p<0.01)$ in body weight compared to the normal group on day 28 (Table 4 ) in a dosedependent manner.

In the present study, the standard drug (alloxan) caused a marked reduction in body weight, whereas AEDN increased body weight significantly. This may have been due to excessive fat utilized from fatty tissue for energy production in the body. The result is similar to that of earlier reports ${ }^{18}$ where dosedependent gain in body weight was seen with plant extract treatment. Alloxan is reported to cause a significant reduction in insulin release by damaging the beta cells (of islets of Langerhans) and induces hyperglycemia in animals, ${ }^{19}$ which results in a decrease in body weight possibly due to catabolism of fats and proteins or by dehydration.

\section{Estimation of blood glucose level and serum analysis}

Blood glucose was estimated at 1, 7, 14, 21, and 28 days. The glibenclamide and DN aqueous extract treated groups (200, 400 $\mathrm{mg} / \mathrm{kg}$ ), showed a significant reduction $(p<0.05)$ from day 7 to 28. Alloxan induced DN aqueous extract @ 400 mg showed a significant reduction in blood glucose level $(p<0.05)$ (Figure 6).
Animals with diabetes induced with alloxan $150 \mathrm{mg} / \mathrm{kg}$ b.w. (i.p.) had elevated blood glucose on day 1 and after 28 days it was reduced a little but was higher than that in the normal group. Alloxan was used to induce diabetes without production of insulin. The result showed a dose-dependent decrease in fasting blood glucose in diabetic rats treated with different doses of the DN extract. This dose-dependent effect compares well with glibenclamide and especially at the dose of $400 \mathrm{mg} / \mathrm{kg}$ body weight the extract produced a more significant reduction in blood glucose level than $5 \mathrm{mg} / \mathrm{kg}$ glibenclamide on day 28 , which may have been due to improved control mechanisms of glycemic as well as insulin secretions from the pancreatic cells of diabetic rats. ${ }^{20}$ Furthermore, oxygen free radicals are involved in the diabetogenic action of alloxan and DN plant extract containing flavonoids and phenolics that are shown to be effective in diabetes due their antioxidant property. 21,22 Thereafter flavonoids are reported to suppress glucose level and also found to be a strong inhibitor of $\alpha$-glucosidase (mainly luteolin). ${ }^{23}$ DN leaf extracts also showed the presence of phenolics in higher content and that is the reason for the decrease in blood glucose level. Identified compounds such as gallic acid, which is a phenolic compound, enhanced insulin secretion and thereafter release from the beta cells ${ }^{24}$ in the present study. On the other hand, rutin, which was identified in DN extract as a flavonoid, was also boosted in reduction of blood glucose in the present study. It acts by increasing the peripheral utilization of

Table 3. Effects of aqueous extract of DN on glucose tolerance test

\begin{tabular}{lllllll} 
Groups & Dose $(\mathrm{mg})$ & $\begin{array}{l}\text { Dose after } 30 \mathrm{~min} \\
(2 \mathrm{~g} / \mathrm{kg})\end{array}$ & $0 \mathrm{~min}$ & $30 \mathrm{~min}$ & $60 \mathrm{~min}$ \\
\hline Normal & Vehicle & Glucose & $87.02 \pm 0.23$ & $197.12 \pm 0.14$ & $189.36 \pm 0.11$ & $186.02 \pm 0.02$ \\
\hline Diabetic induced + standard drug glibenclamide & 5 & Glucose & $83.07 \pm 0.11$ & $103.32 \pm 0.10^{*}$ & $102.11 \pm 0.01^{*}$ & $84.60 \pm 0.11^{*}$ \\
\hline Diabetic induced + DN aqueous leaf extract & 200 & Glucose & $82.86 \pm 0.20$ & $106.11 \pm 0.23^{*}$ & $99.40 \pm 0.20^{*}$ & $92.22 \pm 0.03^{*}$ \\
\hline Diabetic induced + DN aqueous leaf extract & 400 & Glucose & $83.09 \pm 0.03$ & $102.22 \pm 0.20^{*}$ & $97.02 \pm 0.11^{*}$ & $87.22 \pm 0.11$ \\
\hline
\end{tabular}

The results represent mean $\pm \mathrm{SE}(\mathrm{n}=8)$. Data were analyzed by one-way ANOVA, followed by Dunnett comparison test against untreated animals. Values were considered significant where, * ${ }^{p}<0.01:$ Medium significant, SE: Standard error, DN: Decalepis nervosa

Table 4. The effect of 4 week treatment with aqueous extract of DN on body weight ( $\mathrm{g}$ ) after alloxan (150 $\mathrm{mg} / \mathrm{kg}$ i.p.) induced diabetes in rats

\begin{tabular}{|c|c|c|c|c|c|c|}
\hline Group & Dose (mg) & Day 0 (g) & Day 7 (g) & Day 14 (g) & Day 21 (g) & Day 28 (g) \\
\hline Normal control (group-I) & Vehicle & $163.21 \pm 0.01$ & $163.28 \pm 0.22$ & $165.18 \pm 0.10$ & $168.33 \pm 0.01^{*}$ & $169.21 \pm 0.01^{* *}$ \\
\hline $\begin{array}{l}\text { Diabetic control } \\
\text { (group-II) }\end{array}$ & 150 & $174.10 \pm 0.11$ & $172.20 \pm 0.04$ & $164.57 \pm 0.22$ & $156.19 \pm 0.12^{*}$ & $150.11 \pm 0.23^{* *}$ \\
\hline $\begin{array}{l}\text { Diabetic induced + standard } \\
\text { drug glibenclamide } \\
\text { (group-III) }\end{array}$ & 5 & $168.27 \pm 0.22$ & $165.10 \pm 0.20$ & $165.27 \pm 0.11$ & $166.04 \pm 0.24^{*}$ & $167.11 \pm 0.03^{* \star}$ \\
\hline $\begin{array}{l}\text { Diabetic induced }+ \text { DN aqueous } \\
\text { leaf extract } \\
\text { (group-V) }\end{array}$ & 400 & $182.24 \pm 0.31$ & $176.20 \pm 0.20$ & $169.11 \pm 0.01$ & $164.34 \pm 0.21^{*}$ & $156.48 \pm 0.22^{* *}$ \\
\hline
\end{tabular}

The results represent mean \pm SE $(n=8)$. Data were analyzed by one-way ANOVA, followed by Dunnett comparison test against untreated animals. Values were considered significant where, * $p<0.05$ : Low significant, ${ }^{* *} p<0.01$ : Medium significant, SE: Standard error, DN: Decalepis nervosa 
glucose, inhibiting glucose transport from the intestine, which directly causes a significant reduction in blood glucose in both normal and diabetic rats. Glibenclamide (standard) was used in the present investigation because it caused voltage-dependent calcium channel depolarization of the cell membrane and hence increased the intracellular calcium of beta cells, subsequently stimulating insulin secretion to treat diabetes. ${ }^{25}$

\section{Serum lipid analysis}

On day 28, alloxan-treated animals had increased serum glucose, cholesterol, serum triglycerides, LDL, creatinine, and urea and decreased HDL level, but glibenclamide $(5 \mathrm{mg} / \mathrm{kg}$ ) and DN aqueous extract in the two different doses reversed these alloxan-induced changes. Both the extracts showed significant elevation ( $p<0.05$ ) in serum HDL level compared to diabetic control rats after 28 days of treatment in a dose-dependent manner (Table 5).

In the present study, HDL-cholesterol had slightly lower values with a significant $(p<0.05)$ increase in the level of LDLcholesterol in the diabetic control group as compared to the other

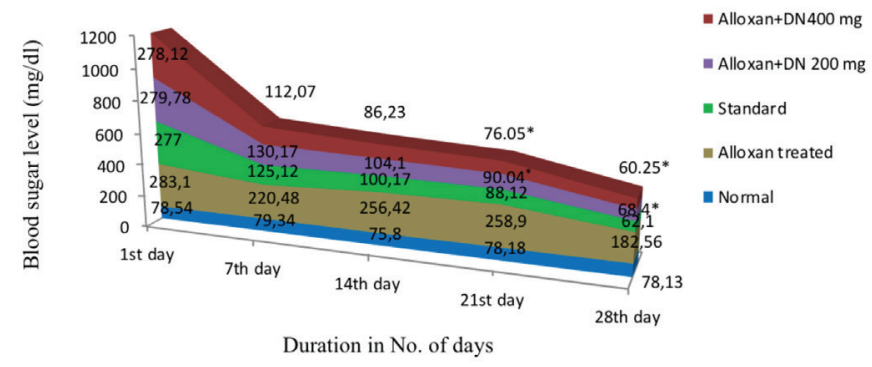

Figure 6. The effect of 4 week treatment with aqueous extract of DN on blood glucose level after alloxan induced diabetes in rats

Values are expressed as mean \pm SE $(n=3)$. * $p<0.05,{ }^{* *} p<0.01,{ }^{* *} p<0.001$ when compared with normal group (ANOVA followed by Dunnet's test) DN: Decalepis nervosa treatment groups. Thereafter, mean values of HDL-cholesterol were significantly $(p<0.05)$ increased, while mean values of LDL-cholesterol were significantly $(p<0.05)$ decreased in both glibenclamide and in DN extract treated groups, which showed their potential to have a hypolipidemic action, consistent with earlier literature ${ }^{26}$ showing the same results. Diabetes results from carbohydrate, protein, and lipid metabolism. Diabetes mellitus results in hyperlipidemia due to abnormalities in lipid metabolism, which in turn leads to atherosclerosis, myocardial infarction, etc. ${ }^{27}$ Increased HDL level plays a significant role in the human body and is known as "beneficial cholesterol" because its increased level is associated with a decreased risk of myocardial infarction by removal of cholesterol from other tissues to the liver. It fosters the removal of cholesterol from peripheral tissue to the liver for catabolism and excretion and competes with LDL receptor sites on arterial smooth muscle cells that partially inhibit LDL uptake and degradation. Furthermore, HDL plays a role in lipid metabolism, complement regulation, immune response, and bringing excess cholesterol to the liver, helping to convert it into bile acids, and finally it is excreted into the small intestine. ${ }^{26}$ An aqueous extract of DN leaves plays a significant role in decreased levels of serum cholesterol, serum glucose, serum triglycerides, LDL, creatinine, and urea and increased level of HDL, and this indicates DN leaves are a good source of antidiabetic drug by reducing the risk of developing heart disease. This may be due to the presence of polyphenolic compounds, especially flavonoids in the leaves, which are incorporated into lipoprotein within the liver or intestine and transported within the lipoprotein particles. Mainly flavonoid consumption is inversely associated with mortality from coronary heart disease and hence flavonoids and phenolics may be located for protection of LDL from oxidation. The same result was revealed earlier. ${ }^{28}$

Table 5. Effect of various groups of DN aqueous extract on serum profile in alloxan $(150 \mathrm{mg} / \mathrm{kg}$, i.p.) induced diabetic rats after 28 days of treatment (fasting condition)

\begin{tabular}{|c|c|c|c|c|c|}
\hline \multirow[t]{2}{*}{ Parameters } & \multicolumn{5}{|l|}{ Group } \\
\hline & $\begin{array}{l}\text { Normal control } \\
\text { (group-I) }\end{array}$ & $\begin{array}{l}\text { Diabetic control } \\
\text { (group-II) }\end{array}$ & $\begin{array}{l}\text { Diabetic induced + } \\
\text { glibenclamide } \\
\text { (group-III) }\end{array}$ & $\begin{array}{l}\text { Diabetic induced + DN } \\
\text { aqueous leaf extract } \\
(200 \mathrm{mg}) \text { (group-IV) }\end{array}$ & $\begin{array}{l}\text { Diabetic induced }+ \text { DN } \\
\text { aqueous leaf extract } \\
(400 \mathrm{mg})(\text { group }-\mathrm{V})\end{array}$ \\
\hline Serum glucose (mg/dL) & $82.83 \pm 0.13$ & $282.40 \pm 0.23^{* *}$ & $145.50 \pm 0.1^{2 \star}$ & $151.33 \pm 0.12^{*}$ & $147.66 \pm 0.24^{*}$ \\
\hline Total cholesterol (mg/dL) & $74.66 \pm 0.20$ & $170.33 \pm 0.10^{* *}$ & $98.20 \pm 0.02^{*}$ & $106.50 \pm 0.10^{*}$ & $100.83 \pm 0.13^{*}$ \\
\hline Serum triglycerides (mg/dL) & $56.83 \pm 0.11$ & $154.00 \pm 0.04^{* *}$ & $93.66 \pm 0.31^{*}$ & $98.00 \pm 0.02^{*}$ & $95.10 \pm 0.11^{*}$ \\
\hline Serum HDL (mg/dL) & $48.83 \pm 0.03$ & $36.16 \pm 0.14^{* *}$ & $46.86 \pm 0.10^{*}$ & $64.33 \pm 0.11^{*}$ & $76.50 \pm 0.40^{*}$ \\
\hline $\begin{array}{l}\text { serum LDL } \\
(\mathrm{mg} / \mathrm{dL})\end{array}$ & $49.05 \pm 0.24$ & $132.74 \pm 0.20^{* *}$ & $51.06 \pm 0.16^{*}$ & $54.78 \pm 0.32^{*}$ & $46.90 \pm 0.41^{*}$ \\
\hline $\begin{array}{l}\text { serum creatinine } \\
(\mathrm{mg} / \mathrm{dL})\end{array}$ & $45.56 \pm 0.21$ & $138.16 \pm 0.10^{* *}$ & $61.80 \pm 0.21^{*}$ & $65.60 \pm 0.34^{*}$ & $63.07 \pm 0.03^{*}$ \\
\hline $\begin{array}{l}\text { Serum urea } \\
(\mathrm{mg} / \mathrm{dL})\end{array}$ & $48.23 \pm 0.22$ & $141.14 \pm 0.11^{* *}$ & $57.12 \pm 0.32^{\star}$ & $64.12 \pm 0.14^{*}$ & $62.03 \pm 0.04^{*}$ \\
\hline
\end{tabular}

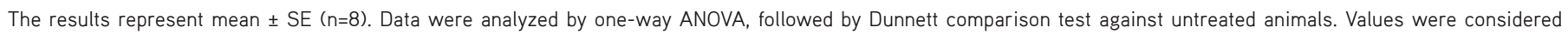
significant where, ${ }^{*} p<0.05$ : Low significant, ${ }^{* *} p<0.01$ : Medium significant

HDL: High-density lipoprotein, DE: Decalepis nervosa, SE: Standard error 


\section{Serum enzyme level}

Activities of serum enzymes such as ALP, AST and ALT were determined. The activity of enzymes is increased much higher (alloxan induced rats) than normal, which gave significant $(p<0.001)$ results in 28 days. Furthermore, diabetic animals treated with the standard drug showed a significant decrease in enzyme activity compared to the animals given only alloxan. With DN aqueous extract it also decreased significantly and the values are close to those of the animals given glibenclamide standard drug ( $p<0.01)$ and the decreased levels are dose dependent over 28 days (Figure 7 ).

In the current study, there was a significant rise in the AST, ALT, and ALP activities in the diabetic control group compared to the normal control group and thereafter the standard drug decreased the values, but they were higher than those in the normal control group, possibly due to cell membrane damage of hepatocytes or due to increased cell membrane permeability. Similar research was also reported previously. ${ }^{29}$ AST and ALT are mainly used as biomarkers to determine liver toxicity. Increased levels of AST, ALT, and ALP in diabetic rats indicate excessive accumulation of glutamate and alanine in the serum of diabetic animals from protein stores. The elevated activities of the serum aminotransferases in the liver indicate cardiovascular disease as well as diabetes among people. The activities of ALT, AST, and ALP in serum are increased due to the leakage of these enzymes (in the liver cytosol) ${ }^{30}$ and as a result diabetes may induce hepatic dysfunction. When DN aqueous extract was administered orally to diabetic animals, it resulted in a significant reduction in serum enzymes such as AST, ALT, and ALP compared to those given just alloxan.

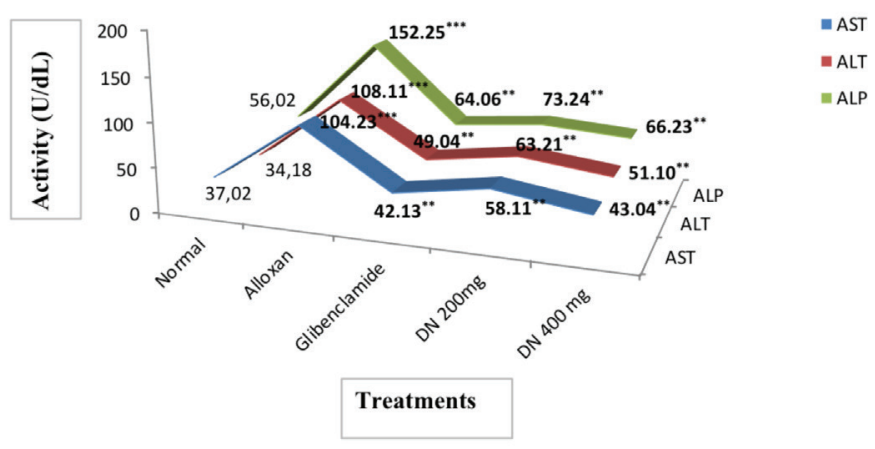

Figure 7. Activity of serum enzymes Values are expressed as mean $\pm \mathrm{SE}$ $(n=8) .{ }^{*} p<0.05,{ }^{* *} p<0.01,{ }^{* *} p<0.001$ (ANOVA followed by Dunnet's test). Diabetic control was compared with normal control $(p<0.001)$ and extract treated groups were compared with the diabetic control $(p<0.01)$

ALP: Alkaline phosphatase, ALT: Alanine aminotransferase, AST: Aspartate aminotransferase

\section{Table 6. Analysis of variance}

\begin{tabular}{l|l|l|l|l} 
Source & DF & Sum of squares & Mean square & F ratio \\
\hline Model & 3 & 86.752150 & 28.9174 & 42.2121 \\
\hline Error & 4 & 2.740200 & 0.6851 & Prob $>$ F \\
\hline C. total & 7 & 89.492350 & & $0.0017^{\star}$ \\
\hline
\end{tabular}

DF: Degrees of freedom, C. total: Number of columns, Prob $>F$ : The $p$ value for the whole model test, * $p<0.05$ : Significant
This indicates the extract has liver protection activity due to the presence of flavonoids as the result is correlated with an earlier study. ${ }^{31}$ Results obtained from the present investigation are clearly in agreement with previous reports related to the hepatoprotective activity of menthi, guduchi, and gymnema herbal extracts reducing the elevated levels of ALT, AST, and ALP, respectively, in diabetes. ${ }^{32,33}$

\section{Effect of different doses of AEDN and body weight of animals on blood glucose level}

The full factorial design was evaluated at a significance level of $p<0.05$. The variance analysis of the whole experiment showed a $p$ value of 0.0017 (Table 6).

Analysis of response to blood glucose showed the actual level by predicting plot with an root mean square error of 1.028 (Figure 8).

The leverage plot showed (Figures 9-11) the significant effect of dose and body weight of animals and its confounding effects with blood glucose level. The data are shown in Table 7 . The response surface graph as shown in Figure 12 explored the relationship between body weight and dose on blood glucose.

Finally, $2 \times 2$ full factorial statistical design studies confirmed the significant effect of body weight and dose on blood glucose reduction. This result confirmed that present endangered

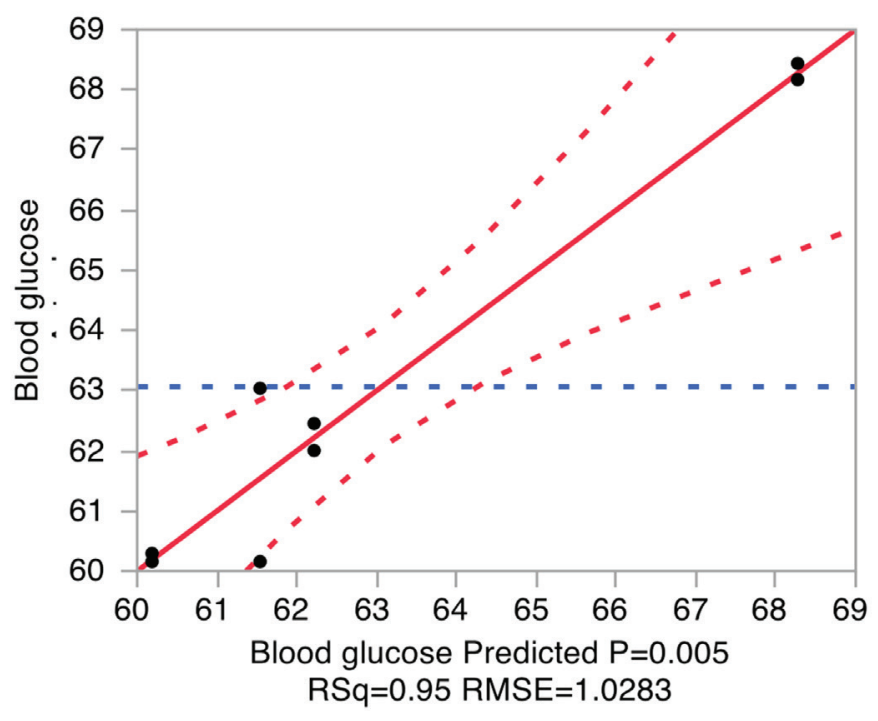

Figure 8 . Actual by predicted plot

Table 7. Effect of dose and body weight and its confounding effects with blood glucose level

\begin{tabular}{l|l|l|l|l}
\hline Term & Estimate & $\begin{array}{l}\text { Standard } \\
\text { error }\end{array}$ & t ratio & Prob $\rangle|t|$ \\
\hline Intercept & 63.065 & 0.363555 & 173.47 & $\left\langle 0.0001^{*}\right.$ \\
\hline Dose (200, 400) & -1.8575 & 0.363555 & -5.11 & $0.0069^{*}$ \\
\hline Body weight (low) & 2.185 & 0.363555 & 6.01 & $0.0039^{*}$ \\
\hline $\begin{array}{l}\text { Dose x body weight } \\
\text { (low) }\end{array}$ & -1.1675 & 0.363555 & -3.21 & $0.0325^{*}$ \\
\hline
\end{tabular}

Prob $>|t|$ : Differentiation between $p$ values of two trial test, ${ }^{*} p<0.05$ : Significant 


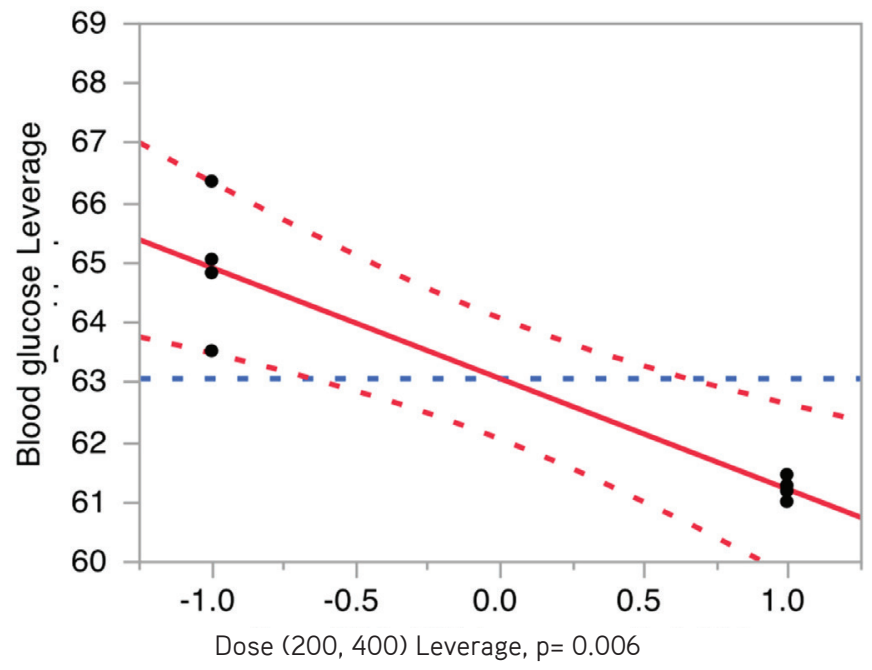

Figure 9. Leverage plot: dose vs blood glucose blood glucose

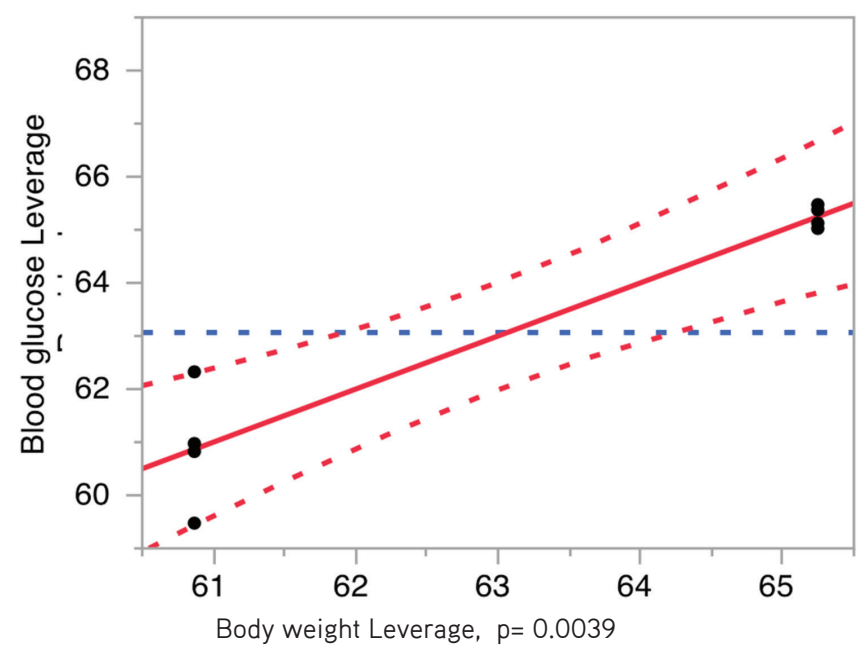

Figure 10. Leverage plot: body weight vs

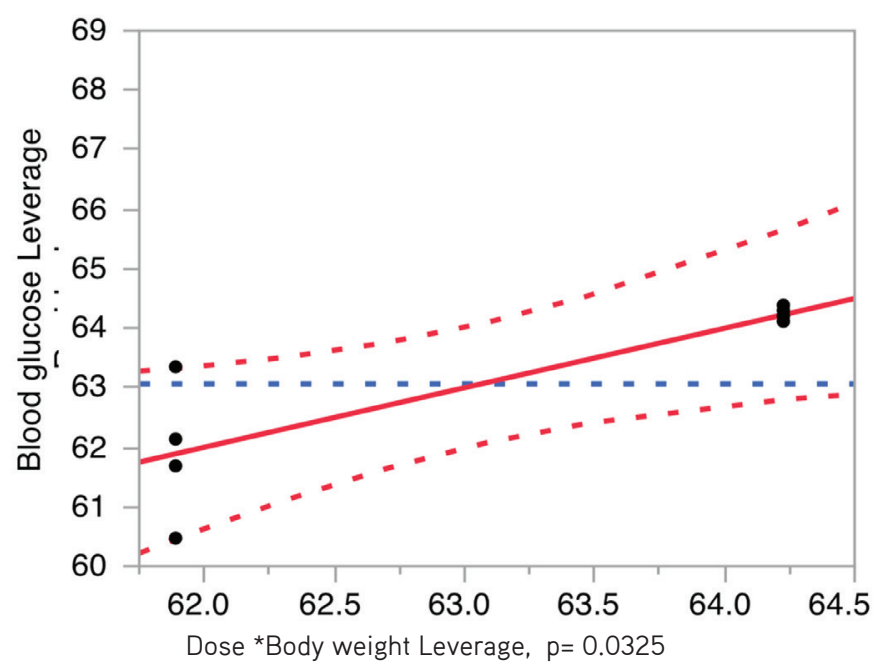

Figure 11. Leverage plot: dose and body weight together vs blood glucose level

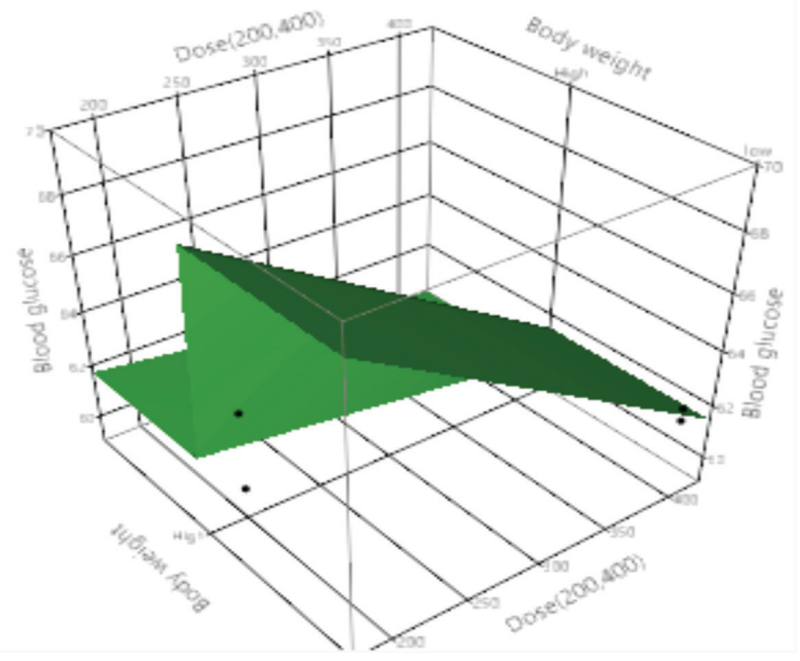

Figure 12. The relationship between body weight and dose on blood glucose

DN species have essential phytoconstituents especially polyphenolic compounds (rutin and gallic acid) that resulted in potential antidiabetic activity.

\section{CONCLUSION}

The present study concludes that various plant constituents, i.e. flavonoids, phenolics, glycosides, and alkaloids, are present in endangered AEDN leaf. TLC and HPLC confirmed rutin and gallic acid in an extract, which may trigger insulin secretion, and demonstrated significant lowering of blood glucose level, serum sugar level, and biochemical parameters, and statistical improvement in the body weight of animals in a dose-dependent manner by enhanced peripheral glucose utilization by direct stimulation of glucose uptake and reduced blood glucose level. The acute oral toxicity study revealed the safe use of all these chemical compounds that are present in DN extract. Hence, it is clear that these compounds could have hypoglycemic effects in diabetic people. Furthermore, for the first time $2 \times 2$ factorial design studies were carried out and showed a significant correlation of dose of DN extract and body weight of animals in lowering of blood glucose level. Therefore, it is ascertained that AEDN leaf has antidiabetic activity. Further research is under way for isolation of active constituents for the discovery of new drugs from DN.

Conflicts of interest: No conflict of interest was declared by the authors. The authors alone are responsible for the content and writing of this article.

\section{REFERENCES}

1. Upendra Rao M, Sreenivasulu M, Chengaiah B, Jaganmohan Reddy K, Madhusudhana Chetty C. Herbal medicines for diabetes mellitus: a review. Int J Pharm Tech Res. 2010;2:1883-1892.

2. Solomon Raju AJ, Venkata Ramana K. Lonta GM. Traditional preparation of a health drink Nannari Sharbat from the root extract of Decalepis hamiltonii Wight \& Arn. Ind J Nat Prod Resources. 2011;2:121-124. 
3. Sharma S, Shahzad A. An Overview on Decalepis: A Genus of Woody Medicinal Climbers. J Plant Sci Res. 2014;1:104.

4. Trease G, Evans SM. Pharmacognosy. 15th ed. London: Bailer Tindal; 2002:23-67.

5. Struchkov P, Beleborodov V, Kolkhir V, Voskoboynikova I, Sawateev A. Comparison of spectrophotometric methods of total flavonoid assay based on complex formation with aluminium chloride as applied to multicomponent herbal drug angionom. J Pharm Negative Results. 2018;9:1-7.

6. Sembiring EN, Elya B, Sauriasari R. Phytochemical Screening, Total Flavonoid and Total Phenolic Content, and Antioxidant Activity of Different Parts of Caesalpinia bonduc (L.) Roxb. Pharmacog J. 2018;10:123-127.

7. Unuofin JO, Otunola GA, Afolavan AJ. Evaluation of acute and subacute toxicity of whole-plant aqueous extract of Vernonia mespilifolia Less. in Wistar rats. J Integr Med. 2018;16:335-341.

8. Kotadiya C, Patel UD, Patel HB, Modi C, Fefar D. Evaluation of effects of Opuntia elatior Mill. fruit juice and quercetin on biochemical parameters and histopathological changes in diabetic rats. Ind J Trad Know. 2018;17:576-583.

9. Kalarani DH, Dinakar A, Senthilkumar N. Antidiabetic activity of ethanolic extracts of Alangium salvifolium and Pavonia zeylanica in streptozotocin induced diabetic rats. Int J Pharm Pharmaceuti Sci. 2012;4:337-339.

10. Ahmet O, Luka CD, Tijjani H, Obidola SM, Joel EB. Anti-diabetic activity of aqueous extract of Curcuma longa (Linn) rhizome in normal and alloxan-induced diabetic rats. Researcher. 2014;6:58-65.

11. Singh A, Srivastav R, Pandey AK. Effect of the seeds of Terminalia chebula on blood serum, lipid profile and urine parameters in STZ induced Diabetic rats. J Pharmacog Phytochem. 2018;7:1-5.

12. Dehpeur MA, Ebrahimzadeh MA, Fazel NS, Mohammad NS. Antioxidant activity of the methanol extract of Ferula assafoetida and its essential oil composition. Grasas Y Aceites. 2009;60:405-412.

13. Sarian MN, Ahmed QU, Mat So'ad SZ, Alhassan AM, Murugesu S, Perumal V, Mohamad SNA S, Khatib A, Latip J. Antioxidant and Antidiabetic Effects of Flavonoids: A Structure-Activity Relationship Based Study. Bio Med Res Int. 2017;2017:8386065.

14. Karima O, Righi S, Belhocin A, Mekness A, Meddah B, Tirtouil A. Phytochemical Study and Antioxidant Activity of Some Anti-Diabetic Plants in the Wilaya of Mascara. J Antimicrob Agents. 2018;4:1-5.

15. Ecobichon DJ. The basis of toxicology testing. New York; CRC press;1997:43-86.

16. Saeed F, Ahmad M. Anti-diabetic and acute toxicity studies of Annona squamosa L. ethanolic leaves extract. Int J Phytomedicine. 2017;9:642647.

17. Sornalakshmi V, Tresina Soris P, Paulpriya K, Packia Lincy M, Mohan VR. Oral Glucose Tolerance Test (OGTT) in Normal Control and Glucose Induced Hyperglycemic Rats with Hedyotis leschenaultiana DC. Int J Toxicol Pharmacol Res. 2016;8:59-62.

18. Tomar RS, Sisodia SS. Antidiabetic activity of Annona squamosa Linn. in alloxan-induced diabetic rats. Int J Green Pharm. 2014:237-241.
19. Balamurugan K, Nishanthini A, Mohan VR. Antidiabetic and antihyperlipidaemic activity of ethanol extract of Melastoma malabathricum Linn. leaf in alloxan induced diabetic rats. Asian Pac J Trop Biomed. 2014:4(Suppl 1):442-448.

20. Jansen J, Lai YC. Regulation of muscle glycogen synthase phosphorylation and kinetic properties by insulin, exercise, adrenaline and role in insulin resistance. Arch Physiol Biochem. 2009;115:13-21.

21. Jafri MA, Aslam M, Javed K, Sing S. Effect of Punica granatum Linn. (flowers) on blood glucose level in normal and alloxan-induced diabetic rats. J Ethnopharmacol. 2000;70:309-314.

22. Syed MA, Vrushabendra SB, Gopkumar P, Dhanapal R, Chandrashekara VM. Anti-diabetic activity of Terminalia catappa Linn. leaf extracts in alloxan-induced diabetic rats. Int J Pharm Technol. 2005;4:36-39.

23. Kim JS, Kwon CS, Son KH. Inhibition of alpha-glucosidase and amylase by luteolin, a flavonoid. Biosci Biotechnol Biochem. 2000;64:24582461.

24. Sameermahmood Z, Raji L, Saravanan T, Vaidya A, Mohan V, Balasubramanyam M. Gallic acid protects RINm5F $\beta$-cells from glucolipotoxicity by its antiapoptotic and insulin-secretagogue actions. Phytother Res. 2010;24(Supll 1):83-94.

25. Serrano-Martín X, Payares G, Mendoza-León A. Glibenclamide, a blockerof $\mathrm{K}+($ ATP) channels, shows antileishmanial activity in experimental murine cutaneous leishmaniasis. Antimicrob Agents Chemother. 2006;50: 4214-4216.

26. Ortega FJ, Gimeno-Bayon J, Espinosa-Parrilla JF, Carrasco JL, Batlle M, Pugliese M, Mahy N, Rodriguez MJ. ATP-dependent potassium channel blockade strengthens microglial neuroprotection after hypoxiaischemia in rats. Exp Neurol. 2012;235:282-296.

27. Yadav AV, Undale VR, Bhosle AV. Antidiabetic activity of Plumeria rubra L. in normal and alloxan induced diabetic mice. Int J Basic Clinic Pharmacol. 2016;5:884-889.

28. Safdar M, Khan A, Khan Khattak MMA, Siddique M. Effect of various doses of cinnamon on blood glucose in diabetic individuals. Pak J Nutri. 2003;2:313-319.

29. Nwufo C, Ene AC, Emejulu AA, Obasi UK, Ene CU. Antidiabetic properties of ethanolic root extract of Mucuna pruriens on alloxan induced diabetic rats. Int J Res Pharm Biosciences. 2017;4:17-29.

30. Rahman MF, Siddiqui MK, Jamil K. Effects of vepacide (Azadirachta indica) on aspartate and alanine aminotransferase profiles in a subchronic study with rats. Hum Exp Toxicol. 2001;20:243-249.

31. Stanely P, Prince M, Menon VP. Hypoglycaemic and other related actions of Tinospora cordifolia roots in alloxan induced diabetic rats. J Ethnopharmacol. 2000;70:9-15.

32. Renuka C, Ramesh N, Saravanan K. Evaluation of the antidiabetic effect of Trigonella foenum-graecum seed powder on alloxan induced diabetic albino rats. Int J pharm Tech Res. 2009;1:1580-1584.

33. El Shafey AAM, El-Ezabi MM, Seliem MME, Ouda HHM, Ibrahim DS. Effect of Gymnema sylvestre R. Br.leaves extract on certain physiological parameters of diabetic rats. J King Saud Univer Sci. 2013;25:135-141. 